\title{
Evaluation of nutritional values, phenolic profile, aroma compounds and biological properties of Pittosporum tobira seeds
}

\author{
Ilhem Rjeibi ${ }^{1 *} \mathbb{D}$, Sana Ncib², Anouar Ben Saad ${ }^{1}$ and Sami Souid ${ }^{1}$
}

\begin{abstract}
Background: Plant essential oils and phenolic compounds are widely used for their medicinal properties. Thus, the aim of this study is to evaluate the nutritional values, the chemical composition, antioxidant activity and anti-hemolytic effects of Pittosporum tobira seeds.

Methods: The aroma compounds were isolated using two methods (Headspace-solid phase microextraction (HS-SPME) and hydrodistillation (HD)) and analyzed by gas chromatography coupled with mass spectrometry (GC-MS). Bioactive phenolic compounds were identified by mean of high-performance liquid chromatography (HPLC-DAD). Reducing power, hydrogen peroxide $\left(\mathrm{H}_{2} \mathrm{O}_{2}\right)$ scavenging and 2,2-diphenyl-1-picrylhydrazyl (DPPH) radical scavenging assays were used to investigate antioxidant activity. Anti-hemolytic activity was evaluated using $\mathrm{H}_{2} \mathrm{O}_{2}$-induced hemolysis of red blood cells (RBC).

Results: Oxygenated sesquiterpenes, sesquiterpene hydrocarbons and oxygenated monoterpenes were the most volatile fractions identified by HD and HS-SPME coupled to GC-MS but their quality and amount were quite different according to the extraction methodology. The main phenolic compounds identified by HPLC were caffeic acid, followed by cinnamic acid and gallic acid. P. tobira seeds essential oils showed significant antioxidant activity in DPPH ( $\left(\mathrm{C}_{50}\right.$ value $\left.=1.5 \mathrm{mg} / \mathrm{mL}\right), \mathrm{H}_{2} \mathrm{O}_{2}$ scavenging assay $\left(I \mathrm{C}_{50}\right.$ value $\left.=159.43 \mu \mathrm{g} / \mathrm{mL}\right)$ and reducing power test $\left(\mathrm{IC}_{50}\right.$ value $\left.=0.982 \mathrm{mg} / \mathrm{mL}\right)$ compared to methanolic extract. Moreover, the results revealed that the essential oil was able to protect $\mathrm{RBC}$ from hemolysis induced by $\mathrm{H}_{2} \mathrm{O}_{2}$. However, the methanolic extract had no effect on $\mathrm{H}_{2} \mathrm{O}_{2}$-induced hemolysis of $\mathrm{RBC}$ as compared to the essential oil and the standard vitamin $C$.
\end{abstract}

Conclusions: $P$. tobira may be used as a new natural source of antioxidant with therapeutic application in diseases caused by reactive oxygen species.

Keywords: Pittosporum tobira Seeds, Phenolic compounds, Aroma compounds, HS-SPME-GC-MS, Antioxidant activity, Anti-hemolytic activity

\section{Introduction}

All over the world, plants are known as a source of nutrients, flavoring additives, oxygen, decoration and biologically active components. The curing effects of plants derived from bioactive substances that are named secondary metabolites which include phenolic acids, flavonoids, terpenoids, tannins, coumarins and

\footnotetext{
* Correspondence: rjeibii@yahoo.fr

${ }^{1}$ Research unit of Macromolecular Biochemistry and Genetic, Faculty of Sciences of Gafsa, 2112 Gafsa, Tunisia

Full list of author information is available at the end of the article
}

other metabolites. These compounds can be synthesized by different plant parts (leaf, root, fruit, flower and stem bark). These metabolites can exert many biological effects including anti-thrombogenic, antimicrobial, antidiabetic, hepatoprotective, antifungal and antioxidant proprieties [1].

Natural products have been found to have the ability to prevent damage caused by reactive oxygen species (ROS). These free radicals have been associated with various diseases, such as cardiovascular, liver injury, atherosclerosis, and cancer diseases [2]. In addition, ROS have been 
implicated in DNA mutations, lipid peroxidation and protein damage [3]. Therefore, many researchers have intensified search to characterize new antioxidant compounds from plant sources usable for clinical applications [4].

The genus Pittosporum forms part of the Pittosporaceae family and includes 200 species which are distributed in the temperate and hot zone of the Earth. Pittosporum species have been used in folk medicine of many countries in the world. P. glabratum from Chine has been used for the treatment of hypertension [5] and the bark of $P$. neelgherrense as antivenom [6]. P. undulatum from Portugal has been used to repair muscles [7]. Australian people used P. phylliraeoides to treat sprains and eczema [8]. This genus provides an excellent source of essential oil components such as monoterpenes, aliphatic hydrocarbons, sesquiterpenes among others compounds. Plant $P$. tobira discovered by the Europeans, is about $2-3 \mathrm{~m}$ high, the leaves are dark green, flowers have a smell similar to orange flowers and the black seeds are enclosed within the encapsulated fruits. Previous studies on the composition of $P$. tobira essential oils obtained by hydrodistillation procedure, have indicated the presence of $\alpha$-pinene as the major component of the flowers for species growing in Iran [9]. This plant has been demonstrated to possess many pharmaceutical properties. Moon and Park [10], reported its protective effects against glutamate-induced neurotoxicity. Moreover, El Dib et al. [11], determined that the $\mathrm{n}$-butanol fraction from $P$. tobira leaves possess antimicrobial activity and cytoprotective effects against breast carcinoma, hepatocellular carcinoma and colon carcinoma cancer cell lines. However, data on the antioxidant activities of seed essential oils from this plant are insufficient. Hence, the aim of the present research is to determine nutritional value, phenolic compound and biological activities of $P$. tobira methanolic extract. The aroma compounds composition of $P$. tobira seeds were also identified by headspace solid phase microextraction and hydrodistillation coupled to gas chromatography coupled with mass spectrometry and their antioxidant and anti-hemolytic capacities were studied.

\section{Materials and methods}

\section{Plant collection}

P. tobira seeds were sampled in June 2015 from Gafsa, southwestern Tunisia $\left(34^{\circ} 25^{\prime} \mathrm{N}\right.$ and $\left.8^{\circ} 47^{\prime} \mathrm{E}\right)$. Voucher samples are stored in the herbarium of the Faculty of Sciences, University of Gafsa, Tunisia. The plant material (200 g) was allowed to air-dry at ambient temperature, grounded to a fine powder using an electric grinder and then kept at $-20{ }^{\circ} \mathrm{C}$ until use.

\section{Physicochemical composition of $P$. tobira seeds}

Moisture, protein, fat, and ash were determined using the AOAC process (1990) [12]. The ash content was determined after heat treatment at $600 \pm 15{ }^{\circ} \mathrm{C}$. Total carbohydrates have been calculated by removing from $100 \%$ the amount of moisture, total fat, protein and ash. Energy has been calculated using this equation: Energy $(\mathrm{kcal})=4 \times(\mathrm{g}$ protein $+\mathrm{g}$ carbohydrate $)+9 \times(\mathrm{g}$ fat $)$. Mineral elements analyses were performed using the method of Rjeibi et al. [13].

\section{Hydrodistillation (HD)}

The essential oil of $P$. tobira seeds was extracted by HD using a Clevenger-type apparatus. Briefly, $50 \mathrm{~g}$ of fine powder of $P$. tobira were immersed in $500 \mathrm{~mL}$ of distilled water and extracted during $3 \mathrm{~h}$. The distilled essential oils were separated using hexane, dried over anhydrous sodium sulfate and kept in a dark glass bottle at $4{ }^{\circ} \mathrm{C}$ until further analysis.

\section{Headspace- solid phase microextraction (HS-SPME)}

HS-SPME technique was used to identify aroma compounds from $P$. tobira. The SPME fiber $75-\mu \mathrm{m}$ carboxen/ polydimethylsiloxane (CAR/PDMS) (preconditioned for 6 min at $240{ }^{\circ} \mathrm{C}$ ) was used for analysis. The dried powdered seeds $(300 \mathrm{mg}$ ) were hermetically sealed in $4 \mathrm{ml}$ vial. The SPME fiber holder was then introduced into the vial. Both sample and fiber were incubated for $30 \mathrm{~min}$ at $60{ }^{\circ} \mathrm{C}$ as predefined extraction time and temperature, respectively. After extraction, the fiber was withdrawn from the sample and thermally introduced into the injection port of the GC-MS for desorption for $3 \mathrm{~min}$ at $240{ }^{\circ} \mathrm{C}$ in splitless mode. The experiment was performed in triplicate. The alkane solution $\left(\mathrm{C}_{7}-\mathrm{C}_{30}\right.$ in $\mathrm{n}$-hexane) performed by headspace extraction during $30 \mathrm{~min}$, at $60^{\circ} \mathrm{C}$, was used to calculate the retention indices.

\section{GC mass spectrometry (GC-MS) analyses}

The Varian CP-3800 GC equipped with the CP-8400 autosampler and Saturn 2200 mass spectrometer was used to analyze the essential oil of $P$. tobira. The injector and detector temperatures were set at 250 and $290{ }^{\circ} \mathrm{C}$, respectively. The VF-5MS capillary column was about $30 \mathrm{~m} \times 0.25 \mathrm{~mm} ; 0.25 \mu \mathrm{m}$ film thickness and the column temperature was programmed from 50 to $280{ }^{\circ} \mathrm{C}$ at $5{ }^{\circ} \mathrm{C} / \mathrm{min}$ and the flow rate of the carrier gas (Helium) was $1.0 \mathrm{~mL} / \mathrm{min}$. A sample of $1.0 \mu \mathrm{L}$ was injected, using splitless mode. Mass spectrometry was in ionization energy mode at $70 \mathrm{eV}$ (scan range $40-450 \mathrm{~m} / \mathrm{z}$ ). Retention indices were determined by injection of the samples under the same condition of series of n-alkanes $\left(C_{7}-C_{30}\right)$ and were calculated according to the equation of Dong et al. [14]. Identification of components was done by comparison of their retention times with those of pure molecules purchased from Sigma-Aldrich and by comparing their mass spectra with our own library of 
spectra built from pure essential oils constituents, NIST library data of the GC-MS system and from published sources.

\section{Methanolic extracts}

$50 \mathrm{~g}$ of the fine grounded seeds were extracted with $500 \mathrm{~mL}$ of methanol (80\%) for $24 \mathrm{~h}$ at room temperature with magnetic stirring. The extracts were centrifuged at $4500 \times \mathrm{g}$ for $10 \mathrm{~min}$ and lyophilized. All of the extracts were kept in the dark at $4{ }^{\circ} \mathrm{C}$ until use.

\section{Determination of total phenolic content}

The total phenolic content (TPC) was determined using a modified colorimetric Folin-Ciocalteu method previously reported by Tlili et al. [15]. Briefly, Folin-Ciocalteu reagent was added to $1 \mathrm{mg}$ of different sample and incubated for $5 \mathrm{~min}$ at room temperature. Next, $7.5 \%$ of $\mathrm{Na}_{2} \mathrm{CO}_{3}$ was added to the mixture and re-incubate for $60 \mathrm{~min}$ at room temperature in the dark. Finally, the absorbance was measured at $760 \mathrm{~nm}$ in a UV-Vis spectrophotometer (Shimadzu, 1240 model, Tokyo, Japan). The analysis was performed in triplicate and TPC was expressed as gallic acid equivalents in milligrams per gram of dry weight basis (mg GAE/g DW).

\section{Determination of total flavonoid content}

The total flavonoids content (TFC) was performed according to the colorimetric assay previously published [15]. One $\mathrm{mL}$ of the sample $(1 \mathrm{mg} / \mathrm{mL})$ was mixed with $0.75 \mathrm{~mL}$ of $5 \%$ sodium nitrite solution. After $5 \mathrm{~min}$, $0.15 \mathrm{ml}$ of $10 \%$ aluminium chloride solution $\left(\mathrm{AlCl}_{3}\right)$ was added and the mixture was left standing for $5 \mathrm{~min}$, and then $0.5 \mathrm{ml}$ of $1 \mathrm{M}$ sodium hydroxide $(\mathrm{NaOH})$ was added to the solution. The volume of the mixture was adjusted to $2.5 \mathrm{~mL}$ with distilled water and mixed well. The absorbance was measured at $510 \mathrm{~nm}$. TFC was expressed as milligrams of catechin equivalent per gram dry weight basis (mg CAE/g DW).

\section{HPLC analysis}

The analyses were performed in high-performance liquid chromatography (HPLC-DAD) with a Varian ProStar HPLC System (Varian 330/ Vis Detector and Varian $230 \mathrm{SDM}$ ) and C18 column (Zorbax, $4.6 \mathrm{~mm} \times 250 \mathrm{~mm}$ ). The mobile phase consisted of acetic acid (solvent A) and methanol (solvent B). The gradient was composed of $0 \%$ (B) for $2 \mathrm{~min}$; $50 \%$ (B) until $30 \mathrm{~min}$ and $80 \%$ (B) for $5 \mathrm{~min}$. The methanolic extracts were utilized in the concentration of $1 \mathrm{mg} /$ $\mathrm{mL}$. The flow rate was $0.9 \mathrm{~mL} / \mathrm{min}$ and the volume injected was $40 \mu \mathrm{L}$. The detected compounds were identified by comparing their retention time with those of injected authentic standards from SigmaAldrich and the use of DAD spectra (200-600 nm).

\section{Antioxidant activity}

\section{$D P P H$ radical scavenging activity}

The effect of $P$. tobira seed extract and essential oil on $\mathrm{DPPH}$ radical was determined following the method reported by Bounatirou, [16]. Adequate solutions of each extract were created to obtain a final volume of $1 \mathrm{~mL}$ and were mixed with $2 \mathrm{~mL}$ of a freshly prepared $\mathrm{DPPH}$ solution $(0.1 \mathrm{mM})$. The After $30 \mathrm{~min}$ of incubation in the dark. The absorbance was measured at $517 \mathrm{~nm}$ on UV-VIS spectrophotometer. Vitamin C and BHT were used as a control. Different concentrations (0.01-10 mg/ $\mathrm{mL}$ ) of the sample were used in order to determine $\mathrm{IC}_{50}$ (amount of sample providing $50 \%$ of scavenging on DPPH). IC50 value was determined from the linear regression equation obtained from the concentrations of the sample and the percentage of inhibition.

$$
\begin{gathered}
\mathrm{I} \%=\left(\text { Absorbance }_{\text {control }}-\text { Absorbance }_{\text {sample }}\right) / \\
\text { Absorbance }_{\text {control }} \times 100 .
\end{gathered}
$$

\section{Hydrogen peroxide $\left(\mathrm{H}_{2} \mathrm{O}_{2}\right)$ scavenging activity}

This test was done according to the method reported by Sahreen et al. [17]. Different sample concentration (1 mL) were mixed with $2.4 \mathrm{~mL}$ of phosphate buffer (0.1 M, pH 7.4) and $0.6 \mathrm{~mL}$ of $\mathrm{H}_{2} \mathrm{O}_{2}$ solution (40 mM). The mixture was shaken vigorously and incubated at room temperature for $10 \mathrm{~min}$ vitamin $\mathrm{C}$ was used as positive control. The absorbance was measured at $230 \mathrm{~nm} . \mathrm{H}_{2} \mathrm{O}_{2}$ scavenging activity $(\%)=1-$ Absorbance sample / Absorbance control $\times 100$.

\section{Reducing power assay}

The reductive potential of studied samples was determined according to the method reported by Bounatirou, [16]. Different sample concentration $(1 \mathrm{~mL})$ were mixed with $1 \mathrm{~mL}$ of phosphate buffer $(0.2 \mathrm{~mol} / \mathrm{L}, \mathrm{pH} 6.6)$ and $1 \mathrm{~mL}$ of potassium ferricyanide $\mathrm{K}_{3} \mathrm{Fe}(\mathrm{CN})_{6}(10 \mathrm{mg} / \mathrm{mL})$. After incubation at $50{ }^{\circ} \mathrm{C}$ for $20 \mathrm{~min}, 1 \mathrm{~mL}$ of trichloroacetic acid $(10 \mathrm{mg} / \mathrm{mL})$ was added to the mixture and centrifuged at $4000 \mathrm{rpm}$ for $10 \mathrm{~min}$. Finally, $\mathrm{FeCl}_{3}(10 \mathrm{mg} / \mathrm{mL})$ was added to the upper layer and left to stand for $10 \mathrm{~min}$ before the measurement of the absorbance at $700 \mathrm{~nm}$ on UV-VIS spectrophotometer (Shimadzu UV-190). The amount of sample providing 0.5 absorbances was determined from the graphical of absorbance at $700 \mathrm{~nm}$. BHT was used as the control.

\section{Oxidative hemolysis inhibition assay}

Methods of assessment of hemolytic activity, focus on the study of the potential damage caused by hydrogen peroxide $\left(\mathrm{H}_{2} \mathrm{O}_{2}\right)$ in erythrocyte membranes. The anti-hemolytic activity of the essential oil was determined following the method reported 
by Lalitha and Selvam, [18] with modifications [13]. Whole fresh human blood from healthy person $(15 \mathrm{~mL})$ was collected in EDTA tubes and centrifuged for $10 \mathrm{~min}$ at $1000 \mathrm{~g}$ at $4{ }^{\circ} \mathrm{C}$. The plasma was removed and obtained red blood cells (RBCs) was suspended in $10 \mathrm{mM}$ PBS ( $\mathrm{pH}$ 7.4). The erythrocytes were washed 3 times with $\mathrm{PBS}$ and finally resuspended in PBS to obtain a solution at $4 \%$. One milliliter of this suspension was mixed with different concentrations $(10-100 \mu \mathrm{g} / \mathrm{mL})$ of the essential oils and methanolic extract and added to $7.5 \mathrm{mM}$ of $\mathrm{H}_{2} \mathrm{O}_{2}$ prepared in PBS. After incubation with agitation for $120 \mathrm{~min}$ at $37^{\circ} \mathrm{C}$, the resulting mixture was centrifuged at $1000 \mathrm{~g}$ for $5 \mathrm{~min}$. Finally, the absorbance of the supernatant was measured at $540 \mathrm{~nm}$ on UV-VIS spectrophotometer (Shimadzu UV-190). Vitamin $C$ was used as the reference $(5-30 \mu \mathrm{g} / \mathrm{mL})$.

Hemolysis inhibition (\%) $=\left(\mathrm{Abs}_{2}-\mathrm{Abs}_{1}\right) /\left(\mathrm{Abs}_{2}-\right.$ $\left.\mathrm{Abs}_{0}\right) \times 100$.

$\mathrm{Abs}_{0}$ (control) is the absorbance of $\mathrm{RBC}$ suspension in $\mathrm{PBS}, \mathrm{Abs}_{1}$ is the absorbance of tested samples with $\mathrm{RBC}$ suspension in $\mathrm{PBS} / \mathrm{H}_{2} \mathrm{O}_{2}$ and $\mathrm{Abs}_{2}$ (induced control) is the absorbance of $\mathrm{RBC}$ suspension in $\mathrm{PBS}$ and $\mathrm{H}_{2} \mathrm{O}_{2}$.

\section{Statistical analysis}

Statistical analysis was performed using the SPSS version 18.0 software. All data were analyzed using a Student's ttest. All tests were performed in triplicate and the results are given as mean values and standard deviation.

\section{Results and discussion}

\section{Chemical composition of $P$. tobira seeds}

The composition in total fat, moisture, protein, carbohydrate and ash contents are shown in Table 1. Carbohydrate seems the predominant component of $P$. tobira seeds, accounting for $71.25 \mathrm{~g} / 100 \mathrm{~g} \mathrm{DW}$, followed by protein with $12.54 \mathrm{~g} / 100 \mathrm{~g}$ DW. According to Pearson [19] plant food that provides more than $12 \%$ of its calorific value from protein is considered a good source of protein. The fat yield of the seed was $5.61 \mathrm{~g} / 100 \mathrm{~g}$ DW. This value was lower than the values reported for oily seeds such as soybean [20]. Therefore, the seed could not be classified as oily seed due to the low oil content.

The seeds showed a considerable amount of ash ( $2.58 \mathrm{~g} /$ $100 \mathrm{~g} \mathrm{DW})$ that may indicate the presence of considerable amounts of inorganic nutrients in this plant. All these values were in the range usually found in some cereals including quinoa, amaranth, purple corn and rice [21].

The energetic contribution of Pittosporum seed was also important $(385.65 \mathrm{kcal} / 100 \mathrm{~g} \mathrm{DW})$. The mineral content of the Pittosporum seeds have been found in $2.58 \mathrm{~g} / 100 \mathrm{~g}$ DW ash content. Also, it is important to investigate the composition of minerals in plants because they have a basic role in our diet. The composition of
Table 1 Proximate composition, mineral content and phytochemical composition of Pittosporum tobira seeds

\begin{tabular}{ll}
\hline Components & Amount \\
\hline Moisture (g/100 g DW) & $8.02 \pm 0.10$ \\
Ash (g/100 g DW) & $2.58 \pm 0.01$ \\
Fat (g/100 g DW) & $5.61 \pm 0.02$ \\
Protein (g/100 g DW) & $12.54 \pm 0.04$ \\
Carbohydrate (g/100 g DW) & $71.25 \pm 0.8$ \\
Energy (kcal/100 g DW) & $385.65 \pm 5.61$ \\
Potassium (K) (mg/100 g) & $723.36 \pm 54$ \\
Sodium (Na) (mg/100 g) & $26.01 \pm 0.42$ \\
Magnesium (Mg) (mg/100 g) & $367.47 \pm 49$ \\
Calcium (Ca) (mg/100 g) & $140 \pm 25$ \\
Iron (Fe) (mg/100 g) & $3.05 \pm 0.03$ \\
Zinc (Zn) (mg/100 g) & $2.01 \pm 0.01$ \\
Manganese (Mn) (mg/100 g) & $1.08 \pm 0.00$ \\
Gallic acid (mg/g) & $1.03 \pm 0.02$ \\
Caffeic acid (mg/g) & $38.57 \pm 0.10$ \\
Ferulic acid (mg/g) & $20.07 \pm 0.08$ \\
p-coumaric acid (mg/g) & $12.85 \pm 0.11$ \\
Cinnamic acid (mg/g) & $5.14 \pm 0.01$ \\
\hline
\end{tabular}

Values are means \pm SD of three separate experiments

macroelements $(\mathrm{K}, \mathrm{Mg}, \mathrm{Ca}, \mathrm{Na})$ and microelements $(\mathrm{Fe}$, $\mathrm{Zn}, \mathrm{Mn}$ ) in seeds of P. tobira is detailed in Table 1. As can be seen, potassium (an essential nutrient for the synthesis of proteins) was found to be the major nutrients detected in the seeds followed by $\mathrm{Mg}>\mathrm{Ca}>\mathrm{Na}$. Ca intake helps to prevent and treat a variety of bone-related illnesses, such as osteoporosis [22]. The predominant microelement in the seed sample was Fe $(3.05 \mathrm{~g} / 100 \mathrm{~g}$ DW). The content of minerals presents similar values to those reported for other cereals and pseudocereals [21]. Moreover, food consumed by the citizens of underdeveloped countries are poor in important elements, namely $\mathrm{Fe}$ and $\mathrm{Zn}$, and increased consumption of $P$. tobira might be useful to reward their daily needs [23].

As we can see, the consumption of $P$. tobira could cover nutritional requirements like quinoa, rice, purple corn, and amaranth. It is demonstrated that such nutraceutical and functional food ingredients have a physiological benefit and provide protection against many chronic diseases. Furthermore, they can exert a role in controlling lipid metabolism and the prevention of dyslipidaemia both in animal models and in humans [24].

\section{Phytochemical analysis}

As shown in this study, the seeds of $P$. tobira are a rich source of phenolic compounds (Table 1). The total phenolic content was $102.7 \mathrm{mg} \mathrm{GAE} \mathrm{/g,} \mathrm{while}$ 
total flavonoid content was $31.62 \mathrm{mg}$ CAE/g DW. These results corroborate previous works which described important polyphenol contents in roots, stem barks and leaves of Pittosporum species [8, 25]. Although the TPC values for $P$. tobira in the present study were lower compared to the ethyl acetate extract of P. mannii (314 mg GAE/g) .

To our best of knowledge, there have been no studies dealing with the identification of polyphenols from $P$. tobira. The HPLC analysis of $P$. tobira seeds recorded at $280 \mathrm{~nm}$ revealed the presence of five phenolic acids (Fig. 1). Phenolic acids were characterized by the predominance of caffeic acid $(38.57 \mathrm{mg} / \mathrm{g})$ followed by ferulic acid $(20.07 \mathrm{mg} / \mathrm{g}), p$-coumaric acid $(12.85 \mathrm{mg} / \mathrm{g})$, cinnamic acid $(5.14 \mathrm{mg} / \mathrm{g})$ and gallic acid $(1.03 \mathrm{mg} / \mathrm{g})$ (Table 1). Phenolic compounds that have been detected in $P$. angustifolium include quercetin glycosides rutin, isoquercitrin dicaffeoylquinic acid [26]. It has been reported that such compounds exhibit diverse therapeutic and biological properties that may justify the use of $P$. tobira in traditional medicine.

\section{Analysis of the aroma compounds of $P$. tobira by HD and HS-SPME}

To our knowledge this study is the first report on the extraction of aroma compounds from $P$. tobira using both HD and HS-SPME methods. The yield of essential oils obtained by HD was $0.84 \%$. A total of 19 components representing $89.494 \%$ of the total essential oils were identified (Table 2). The essential oil of P. tobira seeds was characterized mainly by oxygenated sesquiterpenes (57.517\%) followed by sesquiterpene hydrocarbons (11.794\%) and oxygenated monoterpenes (6.659\%). The most representative components were spathulenol (47.989\%), isospathulenol $(5.798 \%), \quad \delta$-Elemene $(4.195 \%), \quad \lambda$-gurjunene (4.034\%) and camphor (3.657\%). The presence of sesquiterpenes as a major volatile component in the leave from other species such as $P$. viridulum, have been already reported by John et al. [6]. According to [27] Myrcene and n-Nonane were the main components of the essential oil from the flowers and leaves of P. tobira, respectively.

GC-MS analysis of the HS-SPME aroma compounds obtained from P. tobira seed led to the identification of 20 components corresponding to $95.5 \%$ of the total oil content (Table 2). As already seen in HD, sesquiterpenes showed a similar pattern using SPME extraction: oxygenated sesquiterpenes were the major fraction of the essential oil (55.12\%) followed by sesquiterpene hydrocarbons $(21.80 \%)$ and oxygenated monoterpenes (7.82\%). However, some differences in the amounts of major components were detected according to the extraction methods. As appears from Table 2, spathulenol (51.45\%) was the main sesquiterpenes detectable by SPME. The mass spectrum of spathulenol and its compound structure is illustrated in Fig. 2.

As such no quantifiable data is reported on the characterization of the essential oil from Pittosporum species using HS-SPME with which to compare the results of our present study.

The variation of the identified volatile substances, using both methods, are given in Fig. 3. Our results clearly showed that the quality and the amount of the essential oil vary according to the extraction methodology [28]. In fact, HD and HS-SPME have allowed the detection of the majority of volatile compound in the essential oil of $P$. tobira but their proportions are dependent on the separation technique. In addition, HS-

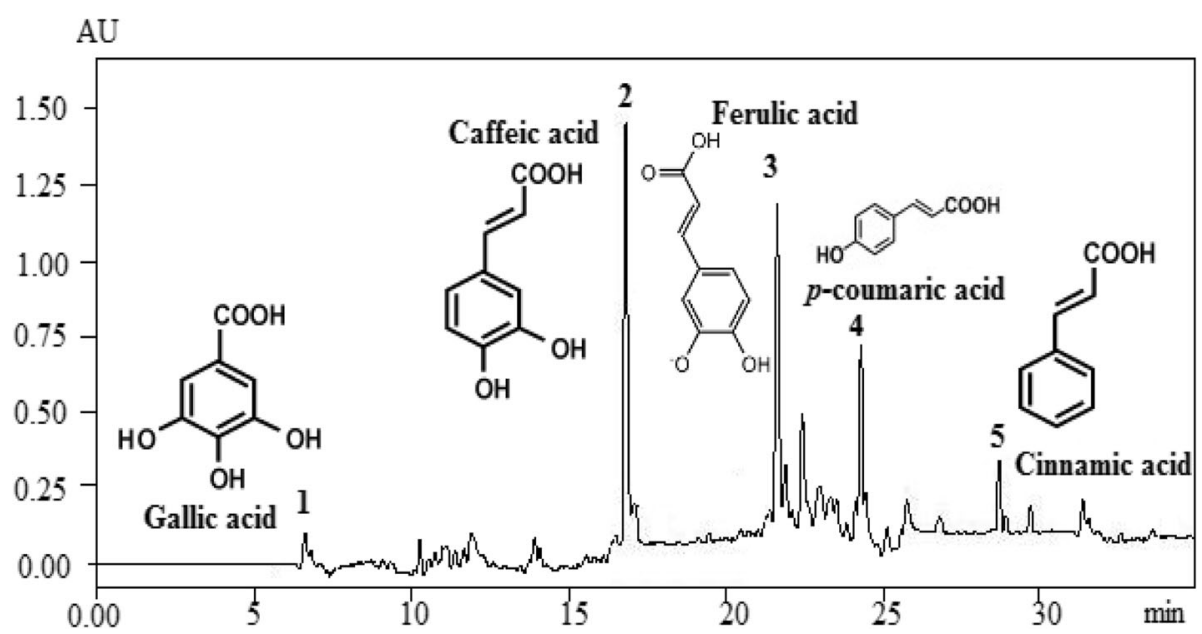

Fig. 1 Chromatogram of the methanolic extract of Pittosporum tobira seeds. 1 correspond to gallic acid peak, 2 caffeic acid, 3 ferulic acid, 4 p-coumaric acid and 5 cinnamic acid 
Table 2 Chemical composition (GC-MS) of Pittosporum tobira seed obtained by HD and HS-SPME

\begin{tabular}{|c|c|c|c|c|c|}
\hline \multirow[t]{2}{*}{ Compounds ${ }^{*}$} & \multirow[t]{2}{*}{$\mathrm{Rl}^{\mathrm{a}}$} & \multicolumn{2}{|l|}{$\% R C$} & \multirow[t]{2}{*}{ Molecular formula } & \multirow{2}{*}{$\begin{array}{l}\text { Identification } \\
\text { methods }\end{array}$} \\
\hline & & SPME & $H D$ & & \\
\hline 1-Butanol & 862 & - & 3.057 & $\mathrm{C}_{4} \mathrm{H}_{10} \mathrm{O}$ & $M S, R I$ \\
\hline 3-Carene & 1007 & - & 0.357 & $\mathrm{C}_{10} \mathrm{H}_{16}$ & $M S, R I$ \\
\hline Eucalyptol & 1020 & - & 1.901 & $\mathrm{C}_{10} \mathrm{H}_{18} \mathrm{O}$ & MS, Rl \\
\hline Artemisia alcohol & 1083 & - & 0.119 & $\mathrm{C}_{10} \mathrm{H}_{18} \mathrm{O}$ & MS, Rl \\
\hline Camphor & 1125 & 7.824 & 3.657 & $\mathrm{C}_{10} \mathrm{H}_{16} \mathrm{O}$ & MS, Rl, Co-GC \\
\hline Borneol & 1165 & - & 2.62 & $\mathrm{C}_{10} \mathrm{H}_{18} \mathrm{O}$ & $M S, R I$ \\
\hline D-Verbenone & 1185 & - & 1.101 & $\mathrm{C}_{10} \mathrm{H}_{14} \mathrm{O}$ & MS, Rl \\
\hline$\delta$-Elemene & 1332 & 0.412 & 4.195 & $\mathrm{C}_{15} \mathrm{H}_{24}$ & MS, Rl \\
\hline Eugenol & 1340 & 0.956 & 2.792 & $\mathrm{C}_{10} \mathrm{H}_{12} \mathrm{O}_{2}$ & $M S, R I$ \\
\hline \&-Cubebene & 1351 & 0.339 & - & $\mathrm{C}_{15} \mathrm{H}_{24}$ & $M S, R I$ \\
\hline \&-Copaene & 1375 & 1.724 & - & $\mathrm{C}_{15} \mathrm{H}_{24}$ & MS, Rl, Co-GC \\
\hline$\beta$-Elemene & 1388 & 1.257 & - & $\mathrm{C}_{15} \mathrm{H}_{24}$ & MS, RI \\
\hline$\beta$-Caryophyllene & 1418 & 1.047 & 0.773 & $\mathrm{C}_{15} \mathrm{H}_{24}$ & MS, RI \\
\hline$\beta$-Copaene & 1427 & 0.873 & - & $\mathrm{C}_{15} \mathrm{H}_{24}$ & MS, Rl \\
\hline \&-Patchoulene & 1452 & 0.337 & - & $\mathrm{C}_{15} \mathrm{H}_{24}$ & $\mathrm{MS}, \mathrm{Rl}$ \\
\hline$\lambda$-Gurjunene & 1467 & 2.068 & 4.034 & $\mathrm{C}_{15} \mathrm{H}_{24}$ & MS, Rl, Co-GC \\
\hline Himachalene & 1471 & 10.493 & - & $\mathrm{C}_{15} \mathrm{H}_{24}$ & MS, RI \\
\hline Germacrene D & 1477 & 0.967 & - & $\mathrm{C}_{15} \mathrm{H}_{24}$ & MS, RI \\
\hline Spathulenol & 1568 & 51.45 & 47.989 & $\mathrm{C}_{15} \mathrm{H}_{24} \mathrm{O}$ & MS, Rl, Co-GC \\
\hline Longifolene & 1576 & 0.372 & - & $\mathrm{C}_{15} \mathrm{H}_{24}$ & MS, RI \\
\hline Isoaromadendrene epoxide & 1579 & 0.107 & 1.215 & $\mathrm{C}_{15} \mathrm{H}_{24} \mathrm{O}$ & $M S, R I$ \\
\hline Globulol & 1582 & 0.165 & - & $\mathrm{C}_{15} \mathrm{H}_{26} \mathrm{O}$ & MS, RI \\
\hline Ledol & 1585 & - & 0.52 & $\mathrm{C}_{15} \mathrm{H}_{26} \mathrm{O}$ & $M S, R l$ \\
\hline Guaiol & 1588 & - & 0.383 & $\mathrm{C}_{15} \mathrm{H}_{26} \mathrm{O}$ & $M S, R l$ \\
\hline Cubenol & 1618 & 0.567 & - & $\mathrm{C}_{15} \mathrm{H}_{26} \mathrm{O}$ & $M S, R l$ \\
\hline Isospathulenol & 1625 & 2.701 & 5.798 & $\mathrm{C}_{15} \mathrm{H}_{24} \mathrm{O}$ & $M S, R I$ \\
\hline T-Cadinol & 1633 & 0.135 & 1.612 & $\mathrm{C}_{15} \mathrm{H}_{26} \mathrm{O}$ & MS, Rl \\
\hline Unknown & 1821 & 10.747 & 2.036 & $\mathrm{C}_{15} \mathrm{H}_{24} \mathrm{O}$ & $M S, R I$ \\
\hline 1-Eicosanol & 2219 & - & 5.335 & $\mathrm{C}_{20} \mathrm{H}_{42} \mathrm{O}$ & $M S, R l$ \\
\hline
\end{tabular}

${ }^{\mathrm{a}} R$ I retention index relative to $\mathrm{C}_{7}-\mathrm{C}_{30}$ n-alknes determined using on a VF-5MS capillary column. $R C$ relative concentration, $M S$ mass spectrum, Co-GC co-injection with authentic compound

SPME allowed a better extraction of sesquiterpene hydrocarbons $(21.80 \%)$ compared to the HD methods. According to Table 2, a remarkable amount of himachalene $(10.493 \%)$ was detected by HS-SPME, while it was completely absent in comparison to the aromas obtained from HD. Moreover, monoterpenes hydrocarbons $(0.357 \%)$ and alcohols $(5.796 \%)$ were not detected using SPME extraction. It is noteworthy that the HS-SPME analysis, had favored a qualitative estimation of the volatile components using a small amount of plant. Finally, further works on the HSSPME are needed to improve the extraction efficiency such as selection of fiber, optimization of extraction time and temperature [29].

\section{Antioxidant activities}

As illustrated in Fig. 4a, the DPPH scavenging activity of all samples increased in a manner dependent on the concentration. At the concentration of $10 \mathrm{mg} / \mathrm{mL}, P$. tobira seeds essential oil showed the highest radical scavenging activity value (89.24\%) but significantly lower than the vitamin $\mathrm{C}$ and BHT $(95.97 \%$ and $93.66 \%$, respectively) $(p<0.05)$. More precisely, the $\mathrm{IC}_{50}$ value of the tested oil $(1.5 \pm 0.21 \mathrm{mg} / \mathrm{mL})$ was less efficient than that of the standards BHT $(0.093 \pm 0.004 \mathrm{mg} / \mathrm{mL})$ and vitamin C (0.0105 $\mathrm{mg} / \mathrm{mL})$ (Table 3$)$.

As appears from Fig. 4b, antioxidant activity determined using the $\left(\mathrm{H}_{2} \mathrm{O}_{2}\right)$ scavenging assay showed results comparable to those obtained with DPPH scavenging 


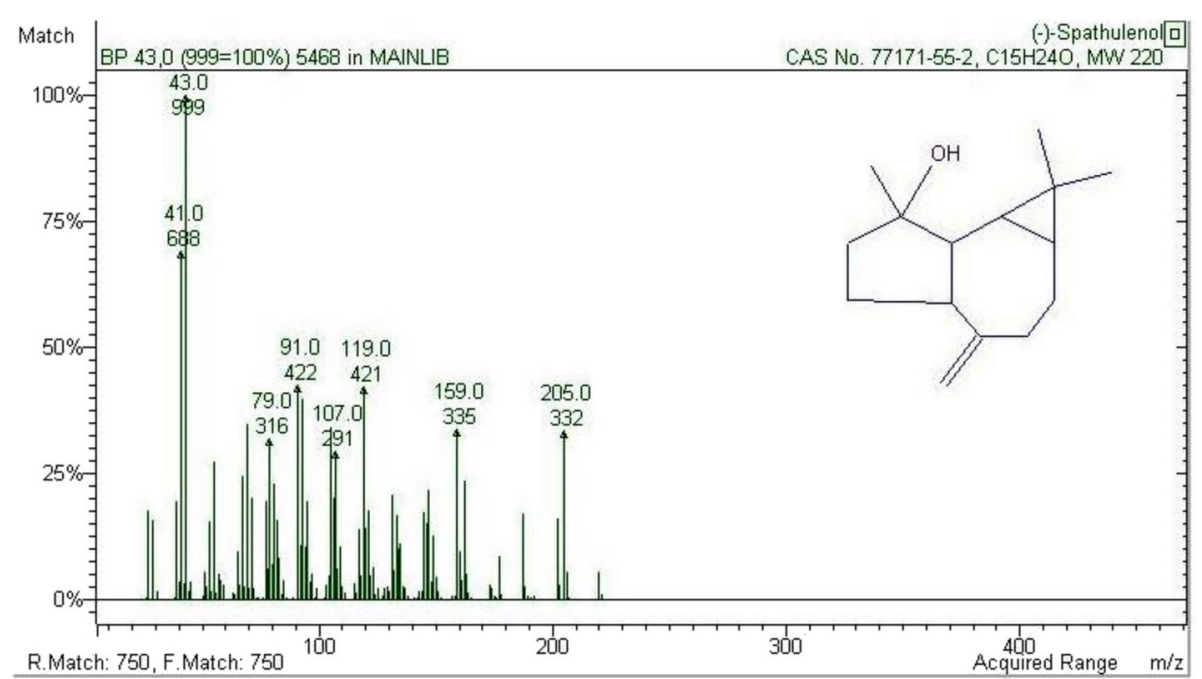

Fig. 2 Mass spectrum and compound structure of spathulenol

activity. Once again, the result suggests that $P$. tobira seeds essential oil exhibited the strongest antioxidant activity. This inhibition was dose-dependent $\left(\mathrm{H}_{2} \mathrm{O}_{2}\right)$ scavenging ability with $\mathrm{IC}_{50}$ values of $159.43 \pm 2.7$ and $308.57 \mu \mathrm{g} / \mathrm{mL}$ for essential oil and methanolic extract, respectively. Thus, $\mathrm{IC}_{50}$ values of essential oil were 1.93fold more efficient than the methanolic extract but less efficient than vitamin $\mathrm{C}\left(\mathrm{IC}_{50}=20.73 \pm 0.78 \mu \mathrm{g} / \mathrm{mL}\right)$ (Table 3).

The reducing power assay was commonly reported as a simple and robust method for measuring antioxidant power. This test is based on the conversion of $\mathrm{Fe}^{3+}$ to $\mathrm{Fe}^{2+}$ under the effect of essential oils. In agreement with DPPH and $\left(\mathrm{H}_{2} \mathrm{O}_{2}\right)$ scavenging assays, reducing power method showed that essential oils exhibited good

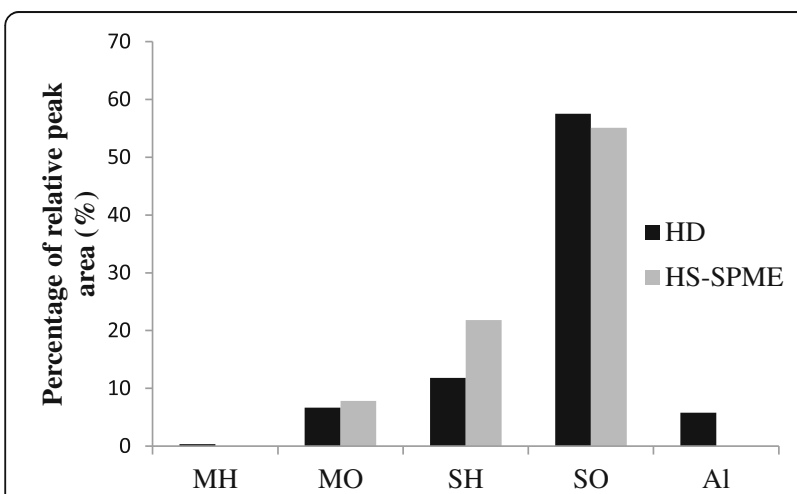

Fig. 3 Schematic diagram representing the variations of the aroma compounds from Pittosporum tobira seeds identified by hydrodistillation (HD) and HS-SPME methods. Monoterpene hydrocarbons $(\mathrm{MH})$, oxygenated monoterpenes $(\mathrm{MO})$, sesquiterpene hydrocarbons $(\mathrm{SH})$, oxygenated sesquiterpenes (SO) and alcohols (Al) antioxidant activity. Thereby, the reducing powers of the tested samples increased when their concentrations were increased (Fig. 4c). As shown in Table 3, the tested oil had slightly lower antioxidant potential than BHT $\left(\mathrm{EC}_{50}=0.384 \pm 0.102 \mathrm{mg} / \mathrm{mL}\right.$ for BHT and $\mathrm{EC}_{50}=0.982 \pm 0.24 \mathrm{mg} / \mathrm{mL}$ for tested oil), but better than methanolic extract.

Overall, the results obtained from the three methods have shown that $P$. tobira exhibited an important antioxidant activity. The obtained results are in agreement with several reports. Notably, the recent study of Dong et al. [14], demonstrated that essential oil from Chuanminshen violaceum had potent antioxidant activity in vitro when compared to other sub-fraction like ethanol, ethyl acetate, methanol and chloroform fraction. However, findings of Mohamed et al. [30] suggested that methanolic extract of Commiphora myrrha exhibited higher DPPH scavenging capacity than the essential oil. These results suggested that there is a relationship between the chemical composition of aromatic plants and their antioxidant activity. According to our results, the antioxidant activity of $P$. tobira seed essential oil might be attributed to the presence of biologically active component such as spathulenol, $\lambda$-gurjunene, camphor and isospathulenol. Spathulenol was found to be the important component in many medicinal plants such as Stachys inflata and Kundmannia syriaca [31, 32]. Additionally, previous studies showed the immunomodulatory effects of spathulenol identified from Salvia spinosa essential oil [33]. Moreover, studies of Martins et al. [34], have demonstrated the anti-tumor potential of spathulenol.

Despite all these investigations, it is difficult to attribute the antioxidant activity to the major active 

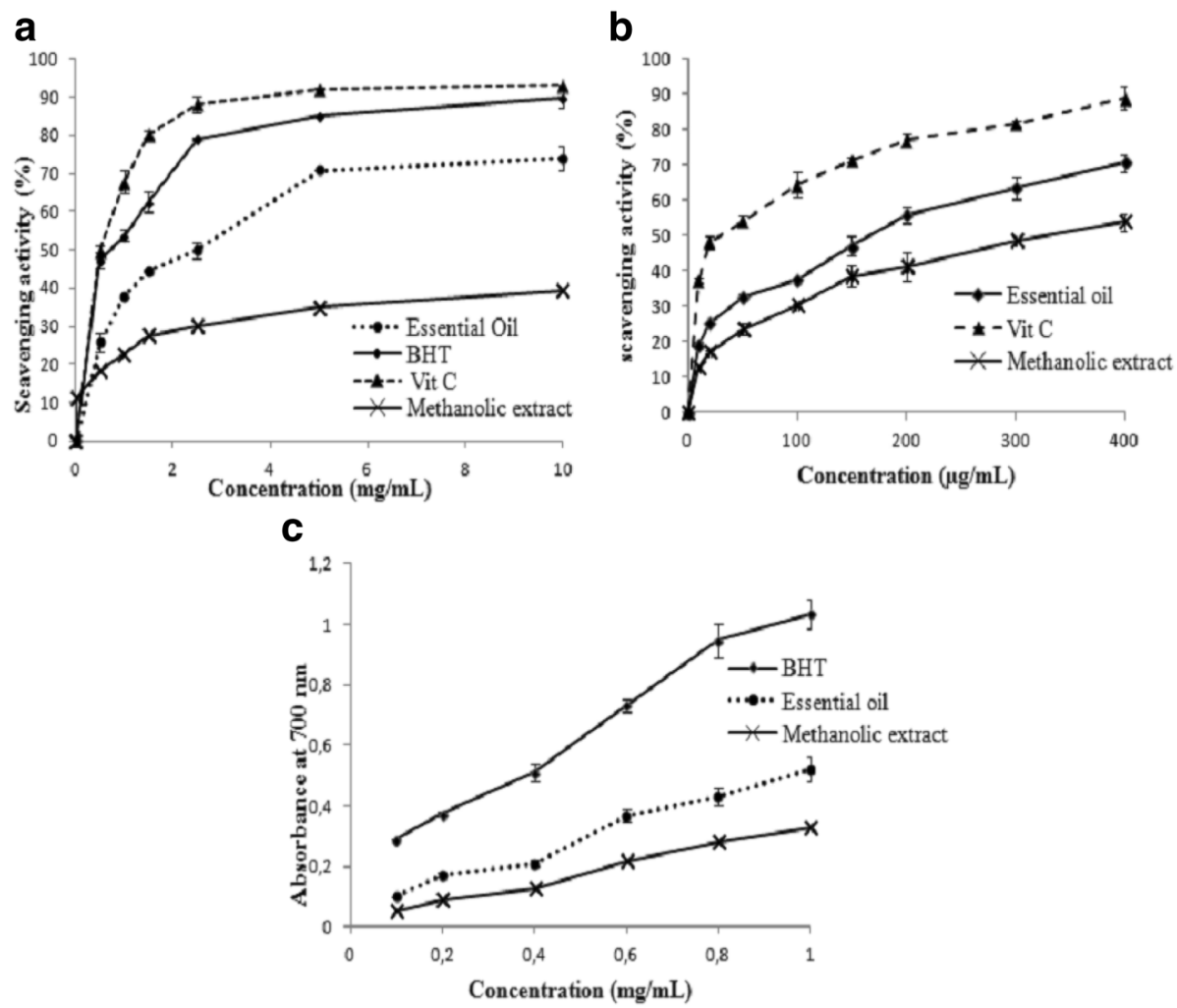

Fig. 4 Antioxidant activities of essential oil from Pittosporum tobira seeds at different concentrations. DPPH free radical-scavenging activities (a), hydrogen peroxide $\left(\mathrm{H}_{2} \mathrm{O}_{2}\right)$ scavenging activity $(\mathbf{b})$ and reducing power $(\mathbf{c})$. Values are means of three replications \pm SD

compounds of the essential oil. Indeed, it is also important to take into account minor compounds for their antioxidant activities [35]. In this regard, the individual compound should be studied.

\section{Inhibition of human erythrocyte hemolysis}

The erythrocytes are the most abundant cells in human body and possess many biological characteristics enabling them to ensure drug transport. The excess of ROS can generate oxidative stress conditions that could damage the erythrocyte membrane lipids and proteins and possibly lead to hemolysis [36]. Given so, in this experimental work, we aimed for the first time to assess whether $P$. tobira prevents damages to erythrocyte membrane or not. Therefore, RBC (red blood cells) were chosen as easy biological design. As shown in Fig. 5, $P$. tobira seeds oil inhibited the hemolysis of erythrocytes in a dose-dependent pattern. The maximum of anti-

Table 3 Antioxidant capacity of essential oil and methanolic extract of Pittosporum tobira seeds

\begin{tabular}{lllll}
\hline & $\begin{array}{l}\text { DPPH scavenging } \\
\text { activity }\left(I C_{50}, \mathrm{mg} / \mathrm{mL}\right)^{*}\end{array}$ & $\begin{array}{l}\text { Reducing power } \\
\left(\mathrm{EC}_{50,} \mathrm{mg} / \mathrm{mL}\right)^{* *}\end{array}$ & $\begin{array}{l}\left(\mathrm{H}_{2} \mathrm{O}_{2}\right) \text { scavenging } \\
\text { activity }\left(\mathrm{IC} \mathrm{C}_{50}, \mu \mathrm{g} / \mathrm{mL}\right)^{* * *}\end{array}$ & $\begin{array}{l}\text { Anti-hemolytic } \\
\text { activity }\left(\mathrm{IC} \mathrm{C}_{50,} \mu \mathrm{gg} / \mathrm{mL}\right)\end{array}$ \\
\hline $\begin{array}{l}\text { Essential oil } \\
\text { Methanolic extract }\end{array}$ & $1.5 \pm 0.21^{\mathrm{c}, \mathrm{d}}$ & $0.982 \pm 0.24^{\mathrm{b}}$ & $159.43 \pm 2.7^{\mathrm{c}}$ & $116.54 \pm 1.8^{\mathrm{c}}$ \\
Synthetic antioxidant & $>10$ & $>1$ & $308.57 \pm 8.14^{\mathrm{f}}$ & - \\
BHT & & & & - \\
Vit C & $0.093 \pm 0.004^{\mathrm{a}}$ & $0.384 \pm 0.102^{\mathrm{a}}$ & - & $16.75 \pm 0.61^{\mathrm{a}}$ \\
\hline
\end{tabular}

Values are mean $\pm \mathrm{SD}, n=3$ (three independent experiments)

Different letters for the same column indicate significant differences at $p<0.05$

"IC50 value was the effective concentrations at which DPPH were scavenged by $50 \%$

***50 value: the effective concentration at which the antioxidant activity was $50 \%$; the absorbance was 0.5 for reducing power

${ }^{* * *}$ IC50 value was the effective concentrations at which $\mathrm{H}_{2} \mathrm{O}_{2}$ were scavenged by $50 \%$

Vit C Vitamin C, BHT Butylated hydroxytoluene 


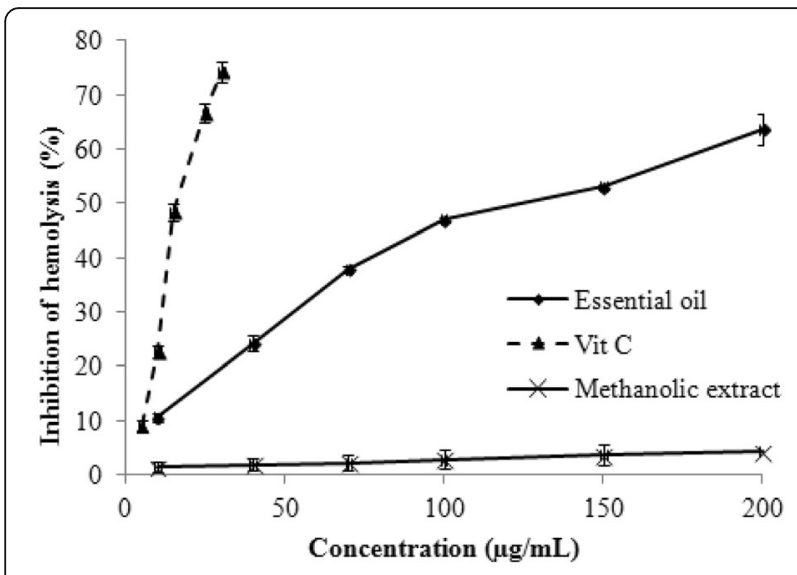

Fig. 5 Effects of the essential oil and methanolic extract from Pittosporum tobira seeds on red blood cell hemolysis induced by $\mathrm{H}_{2} \mathrm{O}_{2}(7.5 \mathrm{mM})$. Values are means of three replications $\pm \mathrm{SD}$

hemolytic activity was observed at $63.64 \%$ with $200 \mu \mathrm{g} /$ $\mathrm{mL}$ of essential oil and the $\mathrm{IC}_{50}$ value was $116.54 \mu \mathrm{g} / \mathrm{mL}$ (Table 3). Results demonstrated that essential oil protected erythrocytes from $\mathrm{H}_{2} \mathrm{O}_{2}$-induced hemolysis. However, the methanolic extract at the concentration from $10 \mu \mathrm{g} / \mathrm{mL}$ to $100 \mu \mathrm{g} / \mathrm{mL}$, have no effects on RBC. Accordingly, essential oil from P. tobira seeds may contain more anti-hemolytic compounds as compared to methanolic extract. Moreover, the antioxidant compounds present in P. tobira might be responsible for the anti-hemolytic activities. These findings are in agreement with the results obtained by Miyazaki et al. [37], who reported the protective effect of natural antioxidant against the degradation of RBC membrane by ROS.

\section{Conclusion}

This study shows, for the first time, the aroma compounds composition of P. tobira using hydrodistillation and HS-SPME coupled to GC-MS. Results revealed that the predominant components are sesquiterpenes and that the quality and the quantity of the essential oil vary according to the extraction methodology. This essential oil showed high antioxidant activity and significant inhibitory activity against $\mathrm{H}_{2} \mathrm{O}_{2}$-induced hemolysis. Our findings suggested that $P$. tobira could be considered as a novel source of natural antioxidant that may be used to protect the human body against disease caused by free radicals.

\section{Abbreviations}

BHT: butylated hydroxytoluene; DPPH: 2, 2-diphenyl-1-picrylhydrazyl; GC/ MS: gas chromatography/mass spectrometry; $\mathrm{H}_{2} \mathrm{O}_{2}$ : hydrogen peroxide; HD: hydrodistillation; HPLC: high-performance liquid chromatography; HS-SPME: Headspace- solid phase microextraction; PBS: phosphate buffer solution; RBC: red blood cells; ROS: reactive oxygen species

\section{Acknowledgements}

The authors express their gratitude to the Ministry of Higher Education and Scientific Research of Tunisia. The authors dedicate this manuscript to the memory of Prof. Imen Said, who passed away on August 2016, for providing constant support to the characterization of plant essential oils using HS-SPME.

\section{Funding}

This work received financial support from Tunisian Ministry of Higher Education and Scientific Research (Grant No. 11/TM06).

\section{Availability of data and materials}

All data generated or analysed during this study are included in this published article.

\section{Authors' contributions}

IR and SS conceived and designed the experiments. IR, SN and ABS performed the experiments. IR and SS analyzed the data. IR, SN and ABS contributed reagents/materials/analysis tools. IR and SS wrote the paper. All authors read and approved the final manuscript.

\section{Ethics approval and consent to participate}

Human blood sampling was performed in the blood bank of the Regional Blood Transfusion Centre of Gafsa, Gafsa, Tunisia (ISSN.0330.7921). All of the blood donors were medically examined and were declared healthy.

\section{Consent for publication}

All authors read and approved the final content of this manuscript for publication.

\section{Competing interests}

The authors declare that they have no competing interests.

\section{Publisher's Note}

Springer Nature remains neutral with regard to jurisdictional claims in published maps and institutional affiliations.

\section{Author details}

${ }^{1}$ Research unit of Macromolecular Biochemistry and Genetic, Faculty of Sciences of Gafsa, 2112 Gafsa, Tunisia. ${ }^{2}$ Common Services Unit for Research, Faculty of Sciences of Gafsa, 2112 Gafsa, Tunisia.

Received: 6 September 2017 Accepted: 20 October 2017

Published online: 30 October 2017

\section{References}

1. Tapas AR, Sakarkar DM, Kakde RB. Flavonoids as nutraceuticals: a review. Trop J Pharmaceutical Res. 2008;7:1089-99.

2. Rani V, Deep G, Singh RK, Palle K, Yadav UC. Oxidative stress and metabolic disorders, pathogenesis and therapeutic strategies. Life Sci. 2016;148:183-93.

3. Anderson D. Antioxidant defenses against reactive oxygen species causing genetic and other damage. Mut Res. 1999;350:103-8.

4. Halder SK, Jana A, Das A, Paul T, Mohapatra PKD, Pati BR, Mondal KC. Appraisal of antioxidant, anti-hemolytic and DNA shielding potentialities of chitosaccharides produced innovatively from shrimp shell by sequential treatment with immobilized enzymes. Food Chem. 2014;158:325-34.

5. Tian-Tian NIE, Huan-Xin ZHAO, Hong BAI. Chemical constituents of Pittosporum glabratum. Chin J Nat Med. 2011;9:0180-4.

6. John AJ, George V, Pradeep NS, Sethuraman MG. Composition and antibacterial activity of the leaf and fruit oils of Pittosporum neelgherrense Wight et Arn. J Essent Oil Res. 2008;20:380-2.

7. Rivera D, Obón C. The ethnopharmacology of Madeira and Porto Santo Islands. J. Ethnopharmacol. 1995;46:73-93.

8. Vesoul J, Cock IE. An examination of the medicinal potential of Pittosporum phylliraeoides, toxicity, antibacterial and antifungal activities. Pharmacogn Commun. 2011;1:8-17.

9. Nickavara B, Amin G, Yosefi M. Volatile constituents of the flower and fruit oils of Pittosporum tobira (Thunb) Ait grown in Iran. Z Naturforsch C. 2004:59:174-6.

10. Moon HI, Park WH. Four carotenoids from Pittosporum tobira protect primary cultured rat cortical cells from glutamate-induced toxicity. Phytother Res. 2010;24:625-8. 
11. El Dib RA, Eskander J, Mohamed MA, Mohammed NM. Two new triterpenoid estersaponins and biological activities of Pittosporum tobira Variegata'(Thunb) WT Aiton leaves. Fitoterapia. 2015;106:272-9.

12. AOAC Official method of analysis. Association of Official Analityical Chemist. Washington: D.C; 1990

13. Rjeibi I, Ben Saad A, Ncib S, Souid S, Alimi H. Comparison of phytochemicals, antimicrobial, and antioxidant capacities in different anatomical parts of Ficus Microcarpa (Moraceae). J Food Biochem. 2017; 41:e12354.

14. Dong H, Zhang Q, Li L, Liu J, Shen L, Li H, Qin W. Antioxidant activity and chemical compositions of essential oil and ethanol extract of Chuanminshen violaceum. Ind Crop Prod. 2015;76:290-7.

15. Tlili N, Elfalleh W, Hannachi H, Yahia Y, Khaldi A, Ferchichi A, Nasri N. Screening of natural antioxidants from selected medicinal plants. Inter J Food Prop. 2013:16:1117-26.

16. Bounatirou S, Smiti S, Miguel MG, Faleiro L, Rejeb MN, Neffati M, Pedro LG. Chemical composition, antioxidant and antibacterial activities of the essential oils isolated from Tunisian Thymus capitatus Hoff. Et link. Food Chem. 2007:105:149-53.

17. Sahreen S, Khan MR, Khan RA. Evaluation of antioxidant activities of various solvent extracts of Carissa opaca fruits. Food Chem. 2010;122:1205-11.

18. Lalitha $\mathrm{S}$, Selvam R. Prevention of $\mathrm{H}_{2} \mathrm{O}_{2}$-induced red blood cell lipid peroxidation and hemolysis by aqueous extracted turmeric. Asia Pac J Clin Nutr. 1999:8:113-4

19. Pearson D. The chemical analysis of foods / David Pearson. Longman Group Ltd. 1976;

20. Abiodun OA, Akinoso R, Olosunde OO, Adegbite JA, Omolola OA Nutritional quality and essential oil compositions of Thaumatococcus danielli (Benn.) tissue and seed. Food Chem. 2014;160:286-91.

21. Nascimento AC, Mota C, Coelho I, Gueifão S, Santos M, Matos AS, Gimenez A, Lobo M, Samman N, Castanheira I. Characterisation of nutrient profile of quinoa (Chenopodium quinoa), amaranth (Amaranthus caudatus), and purple corn (Zea mays L.) consumed in the north of Argentina: proximates, minerals and trace elements. Food Chem. 2014;148:420-6.

22. Gupta UC, Gupta SC. Sources and deficiency diseases of mineral nutrients in human health and nutrition: a review. Pedosphere. 2014:24:13-38.

23. Joy EJM, Ander EL, Young SD, Black CR, Watts MJ, Chilimba ADC, Chilima B, Siyame EWP, Kalimbira AA, Hurst R, Fairweather-Tait SJ, Stein AJ, Gibson RS, White PJ, Broadley MR. Dietary mineral supplies in Africa. Physiol Plant. 2014; 151:208-29.

24. Scicchitano P, Cameli M, Maiello M, Modesti PA, Muiesan ML, Novo S, Palmiero P, Saba PS, Pedrinelli R, Ciccone MM. Nutraceuticals and dyslipidaemia: beyond the common therapeutics. J Funct Foods. 2014:6:11-32.

25. Elansary HO, Skalicka-Woźniak K, King IW. Enhancing stress growth traits as well as phytochemical and antioxidant contents of Spiraea and Pittosporum under seaweed extract treatments. Plant Physiol Bioch. 2016;105:310-20.

26. Bäcker $C$, Jenett-Siems K, Bodtke A, Lindequist U. Polyphenolic compounds from the leaves of Pittosporum angustifolium. Biochem Syst Ecol. 2014;55:101-3.

27. Rodrigues FS, Antunes L, Figueiredo AC, Costa MM, Pereira JDS, Colaço RDR, Hélder H, Miranda S, Barroso JG, Pedro LG, Scheffer JJ. Composition of the leaf, flower and fruit volatile oils of Pittosporum tobira (Thunb.) WT Aiton grown in three locations in Portugal. Flav Fragr J. 2007;22:311-6.

28. Li N, Mao Y, Zhang X. Separation and identification of volatile constituents in Artemisia argyi flowers by GC-MS with SPME and steam distillation. J Chromatogr Sci. 2008;46:401-5.

29. Bogusz S, de Melo ADMT, Zini CA, Godoy HT. Optimization of the extraction conditions of the volatile compounds from chili peppers by headspace solid phase micro-extraction. J Chromatogr A. 2011;1218:3345-50.

30. Mohamed AA, Ali SI, EL-Baz FK, Hegazy AK, Kord MA. Chemical composition of essential oil and in vitro antioxidant and antimicrobial activities of crude extracts of Commiphora myrrha resin. Ind Crop Prod. 2014;57:10-6.

31. Paksoy MY, Diraz E, Diğrak M, Tutar E, Karaman Ş. Essential oil composition and antimicrobial activity of two endemic Kundmannia SCOP. Species from Turkey. Ind Crop Prod. 2016;79:39-46.

32. Ebrahimabadi AH, Ebrahimabadi EH, Djafari-Bidgoli Z, Kashi FJ, Mazoochi A, Batooli H. Composition and antioxidant and antimicrobial activity of the essential oil and extracts of Stachys inflata Benth from Iran. Food Chem. 2010;119:452-8.

33. Ziaei A, Ramezani M, Wright L, Paetz C, Schneider B, Amirghofran Z. Identification of spathulenol in Salvia mirzayanii and the immunomodulatory effects. Phytother Res. 2011;25:557-62.
34. Martins A, Hajdú Z, Vasas A, Csupor-Löffler B, Molnár J, Hohmann J. Spathulenol inhibit the human ABCB1 efflux pump. Planta Med. 2010;76:608.

35. Wang W, Wu N, YG Z, Fu YJ. Antioxidative Activity of Rosmarinus officinalis L. essential oil compared to its main components. Food Chem. 2008;108:1019-22.

36. Matte A, Bertoldi M, Mohandas N, An X, Bugatti A, Brunati AM, Perrotta S. Membrane association of peroxiredoxin-2 in red cells is mediated by the Nterminal cytoplasmic domain of band 3. Free Rad Biol Med. 2013;55:27-35.

37. Miyazaki CMS, Hirota BCK, Delima CP, Dos Santos MC, Paula CD, Chaves SC, Pavan PMN, Miguel MD, Miguel OG. Coumarin isolation and comparative study of biological activities of Pterocaulon alopecuroides DC and Pterocaulon lorentzii Malme. Int J Phytomed. 2013;5:298-301.

\section{Submit your next manuscript to BioMed Central and we will help you at every step:}

- We accept pre-submission inquiries

- Our selector tool helps you to find the most relevant journal

- We provide round the clock customer support

- Convenient online submission

- Thorough peer review

- Inclusion in PubMed and all major indexing services

- Maximum visibility for your research

Submit your manuscript at www.biomedcentral.com/submit
C) Biomed Central 